\title{
Zsuzsa Majer, A Comparative Study of the Ceremonial Practice in Present-Day Mongolian Monasteries (submitted in English),
}

\section{OpenEdition}

\section{Journals}

Electronic version

URL: https://journals.openedition.org/emscat/1656

DOI: $10.4000 /$ emscat. 1656

ISSN: 2101-0013

\section{Publisher}

Centre d'Etudes Mongoles \& Sibériennes / École Pratique des Hautes Études

Electronic reference

"Zsuzsa Majer, A Comparative Study of the Ceremonial Practice in Present-Day Mongolian Monasteries (submitted in English),", Études mongoles et sibériennes, centrasiatiques et tibétaines [Online], 40 | 2009, Online since 28 December 2009, connection on 13 July 2021. URL: http:// journals.openedition.org/emscat/1656; DOI: https://doi.org/10.4000/emscat.1656

This text was automatically generated on 13 July 2021.

(c) Tous droits réservés 


\section{Zsuzsa Majer, A Comparative Study of the Ceremonial Practice in Present-Day Mongolian Monasteries (submitted in English),}

\section{REFERENCES}

$\mathrm{PhD}$ thesis, Eötvös Loránd University, Faculty of Arts, Doctoral School of Linguistics, Program on Mongolian Studies, Budapest, 2008

1 This $\mathrm{PhD}$ thesis gives the description of the ceremonial and ritual system of presentday Mongolian Buddhist monasteries almost twenty years after the beginning of their revival. ${ }^{1}$ The number of ceremonies held depends on the size of the monastery or temple, on the number of lamas, as well as on the tradition followed and the main deities worshipped. In smaller temples, even the daily chanting (cogčin, Tib. tshogs-chen (XE «Tsogchin $»)$ is limited in time and in the number of texts included, while the emphasis is put on reciting texts on individual's request in order to obtain the financial means to keep the temple operating.In other smaller monasteries, only the big festivals are held besides daily ceremonies, whereas in the biggest monasteries, the ceremonial system consists of a wide variety of individual ceremonies, up to ten or fifteen different types a month. In addition to daily chanting, some ceremonies are held once a month, on the same distinguished day of the lunar month, or weekly, while others are held only once in a season. These are completed by the major religious festivals held annually on specific days of the lunar calendar.

2 The Buddhist revival has not yet been studied well: no academic works have been published up to now; only informative but not academic articles in the monthly newspaper of Gandan monastery (XE «Gandan monastery ), Bilgiin melmii, and other similar publications, leaflets of a few bigger temples and sporadic data on the history of 
certain ceremonies in a few works by Mongolian authors give some basic documentation.

3 I started to study the ritual life in Daščoilin monastery in 2001, and continued in the summer of 2004, in order to complete an MA thesis on the terminology concerning the offerings, accessories and pieces of equipment of Mongolian monasteries ${ }^{2}$. This time I also studied the ceremonies of the summer season. I collected the greater part of the material presented in my PhD thesis in 2005-2006 during a 15-month stay in Ulaanbaatar. In order to compare the ceremonial system of Daščoilin monastery (XE "Dashchoilin monastery») with the system of Gandan monastery (XE "Gandan monastery ») and its specialized monastic schools, and with the simpler ceremonial system of smaller temples of Ulaanbaatar, I also studied all the other monasteries and temples of the capital. ${ }^{3}$ The survey I undertook with Krisztina Teleki in Övörhangai (XE « Öwörkhangai »), Dundgov' (XE « Dundgow») and parts of Töv (XE « Töw ») province for the Documentation of Mongolian Monasteries project of the Arts Council of Mongolia in summer 2007, ${ }^{4}$ completed by data from random visits of other countryside temples in five other aimags (Selenge, Bulgan, Arhangai, Dornod and Dornogov'), enabled me to get a complete picture of the current state of Buddhism in the countryside.

In Daščoilin monastery, I completed (XE «Dashchoilin monastery ») personal observation and interviews with informants about the ceremonies and ceremonial system with the analysis of the Tibetan ceremonial books when describing annual ceremonies in detail (and even there only to a limited extent). As for the survey of the other monasteries, I gathered, during personal visits, information from high-ranking lamas and lamas having specific duties such as teachers, shrine supervisors etc., and I collected the written sources available (printed leaflets, books and articles published about the new temples), though these usually only relate to the largest or historically most important temples. In some temples their ceremonial books were possible to study for details of the texts of their daily chanting. The lists of texts recited on request were available in many temples too.

5 Few publications document the historical aspects of ceremonial life - the most complete description being Pozdneev's publication on Buddhism in Mongolia at the end of the nineteenth century. As for the early twentieth century, European travelers' accounts give scant information on the ceremonies. It was therefore necessary for the present study to make personal interviews with old lamas: I interviewed 75 old lamas, now all in their 80's-100's, about the old way of ceremonial practice in their parent monasteries or temples of different sizes. However, historical data from interviews and academic literature were only used for comparisons between the current ceremonial system and the old traditions, as it was not possible to include all data here in this study of present-day ceremonial system.

6 The PhD thesis first gives details of the research methods and insight into the historical background of the revival, then highlights the basic features of Mongolian Buddhism and the peculiarities of its present-day form as practiced today in the lack of monastic environment. The next chapter gives a general view of the ritual activities in Mongolian monasteries, including the ceremonial system, daily chanting and the rituals made on request. Because Daščoilin, the second biggest Mongolian monastery, has a more complex ceremonial system than Gandan - the main monastery in Mongolia today - I chose it as the principal example. Due to the lack of financial means and the 
insufficient number of lamas, especially properly trained ones, some important annual ceremonies have only been revived in a handful of the larger monasteries since 1990. All of these are performed in Daščoilin, while not all in Gandan or in any other Mongolian monastery. The next chapter gives a short description of how this monastery was revived in two temple buildings that survived the purges, and an insight into its current activities. This is followed by an overview of the full ceremonial calendar of this particular monastery. To give more details of the ritual practice to the extent it was possible within the framework of a $\mathrm{PhD}$ thesis, I give a detailed description of the main and most spectacular religious festivals of the ritual year: the Maitreya procession called Maidar ergeh (XE « Maidar ergekh»), the sor zalah (XE "Sor zalakh») (Tib. zor 'phreng) ritual, the cam (XE « Tsam») (Tib. 'chams) ceremony involving sacred dancing ${ }^{5}$, and the hailen (XE « Khailen ») (Tib. khas-len,'oath-taking'), a special 45day oath-taking retreat period, etc. I also give a description of the daily chanting (its texts or constituting parts) as well as the possibilities of reading texts at the request of individuals in this monastery.

One chapter describes the ceremonial practice and readings of other Mongolian temples. I included detailed data on all of the 36 Ulaanbaatar monasteries here, including Gandan monastery (XE «Gandan monastery») and its monastic schools (counted as one), with a short description of their foundation, current situation and ritual activities. I also give a short description of the present-day ceremonial practice in the countryside, that are not different but perhaps more limited due to the difficult economic and social conditions.

8 The appendices include a glossary of the most frequently used Mongolian terms (deity names, names of the most common ceremonies) as well as ananalysis of the daily chanting texts and texts chanted on request of individuals in Mongolian temples, providing explanations and Tibetan/Sanskrit parallels for about one thousand such titles, mainly unavailable till now in academic publications.

\section{NOTES}

1. My research in spring and summer 2007 was supported by the Stein Arnold Exploration Fund of the British Academy, the research exchange program (OTKA 62501) between the Department of Inner Asian Studies, ELTE, Budapest and the Institute of Language and Literature of the Mongolian Academy of Sciences, and also by the Gate of the Dharma Buddhist Foundation (Hungary), in 2005-2006 by the Hungarian Scholarship Board and the Gate of the Dharma Buddhist Foundation (Hungary), in summer 2004 by the Hungarian Scholarship Board, in 2001 by the Pro Renovanda Cultura Hungariae Foundation Student Exchange Section and the Gate of the Dharma Buddhist Foundation (Hungary) and in 1999 by the scholarship of the Hungarian Ministry of Education.

2. On this subject I published two articles: “A mongol szerzetesi ruhadarabok és fejfedők terminológiája" [The Terminology concerning names of garments and hats worn by Mongolian lamas], in Bolor-un Gerel. Kristályfény. Tanulmányok Kara György professzor 70. születésnapjának tiszteletére, I-II kötet, [Bolor-un Gerel. Crystal-Splendour. Essays presented in honour of Professor Kara 
György's 70 birthday, vols. I-II.], ed. Ágnes Birtalan and Attila Rákos, ELTE Belső-ázsiai Tanszék MTA Altajisztikai Kutatócsoport, Budapest, 2005, pp. 503-510; and "Süm hiidiin ed züilstei holbogdoltoi ner tom'yoo" [Mongolian Buddhist Terminology connected to the Material World of Monasteries], in Zaluu mongolč erdemtdiin zuny surguul', olon ulsyn erdem šinžilgeenii hural 2004, Mongol Sudlalyn Ündesnii Holboo, Ulaanbaatar, 2004, pp. 68-81.

3. In 2006-2007, together with Krisztina Teleki I undertook a survey of the ceremonial system and activities of all current Ulaanbaatar monasteries and temples, and a survey of the monasteries and temples of the old capital city, Bogdynhüree, including interviews with 31 old lamas or ex-lamas currently living in Ulaanbaatar. See Zsuzsa Majer and Krisztina Teleki, "Monasteries and Temples of Bogdiin hüree, Ih hüree, or Urga, the Old Capital City of Mongolia in the First Part of the Twentieth Century", 2006; "Survey of Active Buddhist Temples in Ulaanbaatar in 2005 - 2006 with some annotations in 2007", 2007; and "Report On the Interviews Made With Old Monks in 2006 and 2007 in Ulaanbaatar", 2007, Documentation of Mongolian Monasteries project, www.mongoliantemples.net; Zsuzsa Majer and Krisztina Teleki, "A mai Ulánbátor kolostorai és szentélyei" [Present-day Temples of Ulaanbaatar], in Keréknyomok, Orientalisztikai és Buddhológiai folyóirat, Tan Kapuja Buddhista Főiskola, Budapest, 2006/1 (vol. 1.), pp. 147-158.

4. Zsuzsa Majer and Krisztina Teleki, all entries of old and present-day monastic sites of Övörhangai and Dundgov', and of the south-part of Töv aimag (190 sites), Documentation of Mongolian Monasteries project, 2007,www.mongoliantemples.net; Zsuzsa Majer and Krisztina Teleki, "Kolostorok régen és ma a mongol vidéken" [Mongolian Monasteries in the Countryside: Past and Present], in Keréknyomok, Orientalisztikai és Buddhológiai folyóirat, Tan Kapuja Buddhista Főiskola, Budapest, summer 2008 (vol. 4.), pp. 74-88.

5. I published an article on this subject: Zsuzsa Majer, “A Cam tánc hagyományának felélesztése Mongóliában" [Reviving the Tradition of the Cam Dance in Mongolia], in Keréknyomok, Orientalisztikai és Buddhológiai folyóirat, Tan Kapuja Buddhista Főiskola, Budapest, winter 2008 (vol.

3.), pp. 37-62. 